\title{
QUALITY OF Eucalyptus urograndis CHARCOAL PRODUCED IN THE SOUTHERN REGION OF TOCANTINS
}

\author{
Raquel Marchesan ${ }^{1 *}$, Daniela Mendonça², Ana Carolina Caixeta Dias ${ }^{3}$, Renata Carvalho da Silva², José \\ Fernando Pereira ${ }^{1}$, Vanessa Coelho Almeida ${ }^{1}$ \\ ${ }^{1}$ Federal University of Tocantins - UFT, Forest Engineering Departament, Gurupi, TO, Brazil - raqmarchesan@gmail.com*; \\ vanessacoelhoalmeida@uft.edu.br; josé.pereira@uft.edu.br; \\ ${ }^{2}$ Forest Eng., Gurupi, TO, Brazil - renatacsilva@uft.edu.br; \\ ${ }^{3}$ Forest Eng., M.Sc. in Forest and Environmental Sciences, UFT, Gurupi, TO, Brazil - vania.wcaixeta@gmail.com.com.
}

Recebido para publicação: 02/02/2018 - Aceito para publicação: 27/02/2019

\begin{abstract}
Resumo
Qualidade do carvão vegetal de Eucalyptus urograndis produzido na região sul do Tocantins.O objetivo do trabalho foi determinar a qualidade do carvão vegetal do clone de Eucalyptus urophilla x Eucalyptus grandis definindo a densidade básica e retratibilidade da madeira, densidade aparente, índice de quebra, rendimento do carvão vegetal, rendimento em gases condensáveis e não condensáveis, AQI e poder calorífico, comparando os resultados de diferentes posições do tronco e em duas diferentes Rampas de carbonização, Rampa 1 (M1) com taxa de aquecimento de $1,25^{\circ} \mathrm{C} / \mathrm{min}$, temperatura final de $450^{\circ} \mathrm{C}$ e tempo total de 6 horas, e Rampa 2 (M2) com taxa de aquecimento de $1,19^{\circ} \mathrm{C} / \mathrm{min}$, temperatura final de $500^{\circ} \mathrm{C}$ e tempo total de 7 horas. As seis árvores avaliadas foram provenientes de um plantio clonal de seis anos de idade localizado no município de Gurupi, sul do estado do Tocantins. Os corpos de prova para as caracterizações foram confeccionados a partir de discos de madeira retirados das três posições do tronco (base, DAP, topo). A madeira de Eucalyptus urograndis apresentou densidade básica considerada média $\left(0,47 \mathrm{~g} / \mathrm{cm}^{3}\right)$ e boa estabilidade dimensional. $\mathrm{O}$ carvão apresentou rendimento dentro do esperado, alto poder calorífico, influenciado pela temperatura final das Rampas de carbonização, alto teor de carbono fixo, teor de cinzas aceitáveis, além de baixo índice de quebra. Os resultados foram satisfatórios e identificaram a espécie como uma boa fonte energética.

Palavras-chave: retratibilidade, densidade básica da madeira, características energéticas, carvão vegetal.
\end{abstract}

\section{Abstract}

The objective of this work was to determine the quality of the Eucalyptus urophilla $\mathrm{x}$ Eucalyptus grandis clone charcoal, defining the basic density and wood retractability, apparent density, breaking index, charcoal yield, condensable and non-condensable gas yield, AQI and calorific values, comparing the results of different trunk positions and in two different heating ramps, ramp 1 (R1) with a heating rate of $1.25^{\circ} \mathrm{C} / \mathrm{min}$, final temperature of $450^{\circ} \mathrm{C}$ and total of 6 hours, and ramp 2 (R2) with a heating rate of $1.19^{\circ} \mathrm{C} / \mathrm{min}$, final temperature of $500^{\circ} \mathrm{C}$ and total time of 7 hours. The six evaluated trees were from a six-year-old cloned tree plantation located in the municipality of Gurupi, in the south of Tocantins state. The specimens for the characterizations were made from wooden discs removed from three trunk positions (base, DBH, top). The Eucalyptus urograndis wood presented basic density considered average $\left(0.47 \mathrm{~g} / \mathrm{cm}^{3}\right)$ and good dimensional stability. The charcoal presented an expected yield and high calorific value influenced by the final temperature of the heating ramps, high fixed carbon content, acceptable ash content, as well as a low breaking rate. The results were satisfactory and identified the species as a good energy source.

Keywords: Retractability, basic wood density, energetic characteristics, charcoal.

\section{INTRODUCTION}

Wood is used for a variety of purposes, including energy uses. Data from the Food and Agriculture Organization (FAO) of the United Nations (2017) point to wood as the most important source of renewable energy, accounting for about $6 \%$ of the global supply of primary energy. Biomass in Brazil is largely made up of wood and when energy production is evaluated, it can be said that its use is divided into charcoal production (carbonization) and direct consumption of firewood (combustion) (Vale et al., 2002).

Charcoal is only a fraction of the products that can be obtained in the carbonization process. If appropriate collection systems are used, condensable and non-condensable gases can be obtained. Pyroligneous liquor, which is a condensable gas, can be used for energy as well as for several different purposes such as fertilizer, disinfectant, sterilizer, and as a food additive, among others.

Brazil is the largest producer and consumer of charcoal globally, and the only country to produce it commercially on a large scale. The charcoal consumer market is basically made up of the pig iron and ferroalloy 
industries ( $82 \%$ of the coal produced). The use of charcoal has advantages over coke as a reducing agent in the steel industry, for example lower ash, lower sulfur and phosphorus, and is more reactive. Moreover, and especially being more environmentally friendly because it is renewable and less polluting (OLIVEIRA et al., 2010).

Most energy forests plantations consist of the Eucalyptus genus, with characteristics such as rapid growth and considerable wood density, which guarantee easily renewable and good quality charcoal. The most used species in Brazil for these purposes are E. grandis, E. saligna, E. camaldulensis and E. urophylla, as well as their hybrids (SANTOS et al., 2010). E. urograndis is a hybrid developed by crossbreeding E. urophylla and E. grandis.

The first Eucalyptus plantations in Tocantins state appeared in the year 1990 and its main purpose was for farm sustainability. The region had an area of 13,900 hectares planted with eucalyptus until 2006, while plantations had an area of 109,000 hectares in 2012 (ABRAF, 2013). The main purpose of these plantations at the beginning was to supply the demand for wood for pulp production, mainly in Maranhão state, but as this demand was not fulfilled, the wood was directed to producing charcoal for use in steel industries in Tocantins, Goiás and Minas Gerais states.

The growth of this type of plantation in this region can be explained by the concentration of plantations in the south and southeast of Brazil, which caused the price of land to inflate, encouraging producers to migrate to the northern region; in addition, the characteristics of this region are favorable for good forest development, and despite the particularities such as high temperature and prolonged drought, some species are able to adapt and produce satisfactory results.

In this context, the objective of this work was to evaluate the quality of Eucalyptus urograndis charcoal aiming at energy production in the southern region of Tocantins state.

\section{MATERIAL AND METHODS}

The material for this study was obtained from six six-year-old trees in an experimental Eucalyptus urophilla $\mathrm{x}$ Eucalyptus grandis plantation from the Federal University of Tocantins, in Gurupi - TO University Campus, located in the south of the state, at $11^{\circ} 74$ 'S and $49^{\circ} 04^{\prime} \mathrm{W}$, at 280 meters of altitude. The study was conducted at the Forest Products Technology and Utilization laboratory at the Federal University of Tocantins.

Short logs were cut to $50 \mathrm{~cm}$ length at three trunk positions (Base, Diameter at Breast High, Top) of the felled trees for research. They were sent to a carpentry industry to manufacture specimens to determine shrinkage, basic wood density and to produce charcoal. All specimens were cut to approximately $5.0 \times 2.5 \times 2.5 \mathrm{~cm}$ (length $\mathrm{x}$ width $\mathrm{x}$ thickness) and identified with their original position.

\section{Wood Characterization}

Retractability

Wood retractability was obtained by selecting 10 specimens from each position (Base, DBH and top) with well-oriented radial, tangential and transverse planes. They were immersed in water until complete saturation, and after each of which was measured with an analog caliper to determine the saturated dimensions of each plane. They were subsequently put to dry at $0 \%$ humidity in a kiln at a temperature of $103 \pm 2{ }^{\circ} \mathrm{C}$ to constant mass, which were then measured after drying to determine the dry dimensions. The following were then calculated from the resulting data: radial, tangential, longitudinal, volumetric shrinkage and anisotropic factor based on COPANT 462 (1972).

\section{Basic Density}

Basic wood density was determined by the hydrostatic balance method for 20 specimens from each trunk position (Base, DBH and Top), totaling 60 specimens, and calculated based on ASTM D-2395 (ASTM, 2005).

\section{Charcoal Production and Energy Characterization}

For the charcoal production, the same 20 specimens obtained from each trunk position were used to determine the basic density, totaling 60 specimens. The specimens were charred in a muffle kiln adapted to capture pyroligneous liquor and programmed with two different carbonization increases (Table 1). Two ramped increases were then performed for each trunk position (base, DBH and top) using 10 specimens for each Ramp, totaling six pyrolysis groups. The first Ramp had a heating rate of $1.25^{\circ} \mathrm{C} / \mathrm{min}$, final temperature of $450^{\circ} \mathrm{C}$ and total time of 6 hours. The second Ramp had a heating rate of $1.19^{\circ} \mathrm{C} / \mathrm{min}$, final temperature of $500^{\circ} \mathrm{C}$ and total time of 7 hours. The specimens were brought to a dry chamber at $103 \pm 2{ }^{\circ} \mathrm{C}$ for 24 hours prior to carbonization to remove moisture from the wood. 
Table 1. Temperature and carbonization time as a function of the carbonization run.

Tabela 1. Temperatura e tempo de carbonização em função da Rampa de carbonização.

\begin{tabular}{|c|c|c|c|c|c|c|c|c|}
\hline \multirow{2}{*}{ Ramp } & \multicolumn{6}{|c|}{ Temperature ${ }^{\circ} \mathrm{C}$} & \multirow{2}{*}{$\begin{array}{l}\text { Heating Rate } \\
{ }^{\circ} \mathrm{C} / \mathrm{min}\end{array}$} & \multirow{2}{*}{$\begin{array}{l}\text { Total } \\
\text { Time }\end{array}$} \\
\hline & 150 & 200 & 250 & 350 & 450 & 500 & & \\
\hline 1 & 1 hour & 1 hour & $1 \mathrm{~h} 30$ & $1 \mathrm{~h} 30$ & 1 hour & - & 1.25 & 6 hours \\
\hline 2 & 1 hour & 1 hour & $1 \mathrm{~h} 30$ & $1 \mathrm{~h} 30$ & 1 hour & 1hour & 1.19 & 7 hours \\
\hline
\end{tabular}

The following were calculated after carbonization: charcoal yield, condensable and non-condensable gases, bulk density, gravimetric yield, breaking index, immediate chemical analysis (ICA) and calorific value.

\section{Charcoal Yield, Condensable and Non-Condensable Gases}

The adaptation to collect pyroligneous liquor made it possible to define the yield in charcoal, condensable and non-condensable gases. The reactor was first weighed with the wood prior to carbonization, as well as all parts of the pyrolysis system. After carbonization, all parts of the system containing liquor as well as the reactor with charcoal were weighed again to determine the yields (Equations 1,2 and 3).

$Y c=\frac{M c}{M w} * 100$

Where: $\mathrm{Yc}=$ charcoal yield $(\%) ; \mathrm{Mc}=$ mass of charcoal $(\mathrm{g}) ; \mathrm{Mw}=$ wood mass $(\mathrm{g})$.

$Y c g=\frac{M l}{P m M w} * 100$

Where: $\mathrm{Ycg}=$ condensable gas yield $(\%) ; \mathrm{Ml}=$ mass of pyroligneous liquor $(\mathrm{g}) ; \mathrm{Mw}=$ wood $\operatorname{mass}(\mathrm{g})$.

$Y n c g=100-Y c-Y c g$

Where: $Y n c g=$ non-condensable gas yield $(\%) ; \mathrm{Yc}=$ charcoal yield $(\%) ; \mathrm{Ycg}=$ condensable gas yield $(\%)$.

\section{Apparently density}

Charcoal apparent density was defined as the ratio between the mass of charcoal weighed on an analytical scale and its volume, which was calculated by measuring its dimensions (length, width and thickness) with an analog caliper, as presented in Equations 4 and 5.

$\operatorname{Dap}=\frac{M}{V}$

Where: Dap = apparent density $\left(\mathrm{g} / \mathrm{cm}^{3}\right) ; \mathrm{M}=$ mass of charcoal $(\mathrm{g}) ; \mathrm{V}=$ volume of charcoal $\left(\mathrm{cm}^{3}\right)$.

$V=l * w * t$

Where: $\mathrm{V}=$ volume of charcoal $\left(\mathrm{cm}^{3}\right) ; 1=$ length, $\mathrm{w}=$ width and $\mathrm{t}=$ thickness $(\mathrm{cm})$.

\section{Breaking Index}

The coal strength test was determined according to its breaking index based on ABNT NBR 7416/84 (ABNT, 1984), in which each charcoal was subjected to a free fall of $1830 \mathrm{~mm}$ and this fall test was repeated up to 3 times. The charcoal was weighed before and after testing, and the largest fragment resulting after the fall was weighed. The breaking index was determined using Equation 6.

$B i=\left(1-\frac{f}{F}\right) * 100$

Where: $\mathrm{Bi}=$ Breaking Index $(\%) ; \mathrm{f}=$ largest fragment after testing $(\mathrm{g}) ; \mathrm{F}=$ coal sample before testing $(\mathrm{g})$. 


\section{Immediate Chemical Analysis (ICA)}

An analysis of the immediate chemical composition of the charcoal was performed based on ASTM D 1762/84 (ASTM, 2007). The produced charcoals were ground separately producing 10 samples sorted by position origin and carbonization Ramp, totaling 60 samples. They were placed in porcelain crucibles, weighing the moist samples first, then placed in a drying kiln at approximately $100^{\circ} \mathrm{C}$ for $30 \mathrm{~min}$. to obtain the dry mass. Finally, the crucibles with the charcoal samples were sent to a muffle kiln, where they remained first for 7 minutes at $900^{\circ} \mathrm{C}$ to determine the volatile materials, and then for another 7 hours at $700^{\circ} \mathrm{C}$ to determine the fixed carbon and ash contents.

\section{Calorific Power}

The calorific power of charcoal was determined based on the methodology of Do Vale et al. (2002), according to Equation 7:

$C P=4934,43+33,27 * F C$

Where: $\mathrm{CP}=$ calorific power $\left(\mathrm{kcal} . \mathrm{kg}^{-1}\right)$ and $\mathrm{FC}=$ fixed carbon percentage $(\%)$

\section{Statistical analysis}

The experimental design was completely randomized with a $3 \times 2$ factorial arrangement considering the origin position factors of the samples and the two different carbonization Ramps. Statistical analysis was performed by the Assistat and Excel programs. The Tukey test was used for immediate chemical analysis and calorific value wood quality parameters. The Kruskal-Wallis test was used for other parameters.

\section{RESULTS}

\section{Wood Characterization}

Table 2 presents the analysis of variance for the physical properties of wood parameters.

Table 2. ANOVA of the basic density and retractability of E. urograndis wood.

Tabela 2. ANOVA da densidade básica e retratibilidade da madeira de $E$. urograndis.

\begin{tabular}{lc}
\hline \multicolumn{1}{c}{ Parameters } & F \\
\hline Basic wood density $\left(\mathrm{g} / \mathrm{cm}^{3}\right)$ & $33.76 * *$ \\
Tangential shrinkage $(\%)$ & $9.19 * *$ \\
Radial shrinkage $(\%)$ & $0.04 \mathrm{~ns}$ \\
Longitudinal shrinkage $(\%)$ & $0.21 \mathrm{~ns}$ \\
Volumetric shrinkage $(\%)$ & $3.46 *$ \\
Anisotropic factor & $1.82 \mathrm{~ns}$ \\
\hline
\end{tabular}

$*$ significant at $5 \%$ probability level $(.01=<\mathrm{p}<.05) ; * *$ significant at $1 \%$ probability level $(\mathrm{p}<.01)$; ns - not significant $(\mathrm{p}>=.05)$

In Table 2, the analysis of variance of basic density and tangential shrinkage were significant at $1 \%$ probability level, while the volumetric shrinkage was significant at a 5\% probability level. Radial and longitudinal retraction and anisotropic factor were not significant.

Table 3 shows the average values for the physical properties of wood parameters. 
Table 3. Basic density and retractability of E. urograndis wood.

Tabela 3. Médias de densidade básica e retratibilidade da madeira de $E$. urograndis.

\begin{tabular}{|c|c|c|}
\hline Parameters & Positions & \\
\hline \multirow{3}{*}{ Basic Wood Density $\left(\mathrm{g} / \mathrm{cm}^{3}\right)$} & Base & $\begin{array}{c}0.50 \mathrm{a} \\
(0.01 ; 2.86)\end{array}$ \\
\hline & $\mathrm{DBH}$ & $\begin{array}{c}0.46 \mathrm{~b} \\
(0.01 ; 2.47)\end{array}$ \\
\hline & Top & $\begin{array}{c}0.44 \mathrm{c} \\
(0.02 ; 3.73) \\
\end{array}$ \\
\hline \multirow{3}{*}{ Tangential shrinkage (\%) } & Base & $\begin{array}{c}7.13 \mathrm{a} \\
(0.75 ; 10.58)\end{array}$ \\
\hline & $\mathrm{DBH}$ & $\begin{array}{c}6.31 \mathrm{~b} \\
(0.51 ; 8.04)\end{array}$ \\
\hline & Top & $\begin{array}{c}6.12 b \\
(0.33 ; 5.37) \\
\end{array}$ \\
\hline \multirow{3}{*}{ Radial retraction (\%) } & Base & $\begin{array}{c}4.35 \mathrm{a} \\
(0.80 ; 18.50)\end{array}$ \\
\hline & DBH & $\begin{array}{c}4.27 \mathrm{a} \\
(0.67 ; 15.66)\end{array}$ \\
\hline & Top & $\begin{array}{c}4.28 \mathrm{a} \\
(0.41 ; 9.59)\end{array}$ \\
\hline \multirow{3}{*}{ Longitudinal shrinkage (\%) } & Base & $\begin{array}{c}0.16 \mathrm{a} \\
(0.21 ; 131.15)\end{array}$ \\
\hline & $\mathrm{DBH}$ & $\begin{array}{c}0.23 \mathrm{a} \\
(0.31 ; 137.91)\end{array}$ \\
\hline & Top & $\begin{array}{c}0.18 \mathrm{a} \\
(0.11 ; 63.65) \\
\end{array}$ \\
\hline \multirow{3}{*}{ Volumetric shrinkage (\%) } & Base & $\begin{array}{c}11.64 \mathrm{a} \\
(1.21 ; 10.38)\end{array}$ \\
\hline & DBH & $\begin{array}{c}10.81 \mathrm{ab} \\
(0.93 ; 8.61)\end{array}$ \\
\hline & Top & $\begin{array}{c}10.58 \mathrm{~b} \\
(0.59 ; 5.53)\end{array}$ \\
\hline \multirow{3}{*}{ Anisotropic factor } & Base & $\begin{array}{c}1.66 \mathrm{a} \\
(0.35: 21.12)\end{array}$ \\
\hline & $\mathrm{DBH}$ & $\begin{array}{c}1.53 \mathrm{a} \\
(0.24 ; 15.75)\end{array}$ \\
\hline & Top & $\begin{array}{c}1.44 \mathrm{a} \\
(0.15 ; 10.47)\end{array}$ \\
\hline
\end{tabular}

The average followed by the same letter in the column do not differ statistically from each other by the Tukey test (5\%). The values in parentheses respectively correspond to standard deviation and coefficient of variation $(\%)$.

\section{Characterization of Charcoal}

Table 4 presents the average yield values in charcoal, condensable and non-condensable gases of $E$. urograndis wood.

Table 4. Averages of charcoal yield in condensable and non-condensable gases of $E$. urograndis wood.

Tabela 4. Médias de rendimento em carvão, em gases condensáveis e não condensáveis de $E$. urograndis.

\begin{tabular}{cccc} 
& & \multicolumn{2}{c}{ Carbonization Rises } \\
\hline Parameters & Positions & $\mathbf{4 5 0}^{\circ} \mathbf{C}$ & $\mathbf{5 0 0}^{\circ} \mathbf{C}$ \\
\hline \multirow{2}{*}{$\begin{array}{c}\text { Charcoal yield } \\
(\%)\end{array}$} & Base & 33.33 & 32.93 \\
& DBH & 31.17 & 31.17 \\
\hline \multirow{2}{*}{ Condensable gas } & Top & 30.49 & 30.12 \\
yield (\%) & Base & 47.62 & 44.51 \\
& DBH & 45.45 & 46.10 \\
Non-condensable & Top & 50.00 & 48.19 \\
gas yield $(\%)$ & Base & 19.05 & 22.56 \\
& DBH & 23.38 & 22.73 \\
\hline
\end{tabular}

FLORESTA, Curitiba, PR, v. 49, n. 4, p. 691 - 700, out/dez 2019

Marchesan, R. et.al.

ISSN eletrônico 1982-4688 
Table 5 presents average values of apparent density and breaking index of E. urograndis charcoal.

Table 5. Average values of apparent density, gravimetric yield and breaking rate of $E$. urograndis charcoal. Tabela 5. Médias de densidade aparente, rendimento gravimétrico e índice de quebra do carvão de $E$. urograndis.

\begin{tabular}{cccc}
\hline & & \multicolumn{2}{c}{ Carbonization Ramps } \\
\hline Parameters & Positions & $\mathbf{4 5 0}^{\circ} \mathbf{C}$ & $\mathbf{5 0 0}^{\circ} \mathbf{C}$ \\
\hline & Base & $0.35 \mathrm{~B}$ & $0.35 \mathrm{~B}$ \\
Apparent density & $(0.02 ; 5.47)$ & $(0.02 ; 5.59)$ \\
$\left(\mathrm{g} / \mathrm{cm}^{3}\right)$ & $\mathrm{DBH}$ & $0.26 \mathrm{AB}$ & $0.23 \mathrm{~A}$ \\
& & $(0.02 ; 6.61)$ & $(0.02 ; 7.18)$ \\
& Top & $0.23 \mathrm{~A}$ & $0.26 \mathrm{AB}$ \\
& & $(0.04 ; 15.84)$ & $(0.01 ; 4.98)$ \\
\hline Breaking index $(\%)$ & Base & $0.74 \mathrm{~B}$ & $0.38 \mathrm{AB}$ \\
& & $(0.17 ; 22.42)$ & $(0.28 ; 73.55)$ \\
& DBH & $0.19 \mathrm{~A}$ & $0.15 \mathrm{~A}$ \\
& & $(0.16 ; 83.70)$ & $(0.15 ; 99.05)$ \\
& Top & $0.15 \mathrm{~A}$ & $0.32 \mathrm{AB}$ \\
\end{tabular}

The average rate followed by the same letter in the row and column do not differ statistically from each other by the Kruskal-Wallis test (5\%). The values in parentheses correspond respectively to standard deviation and coefficient of variation (\%).

Table 6 presents the statistical analyzes of variance and significance of the ICA parameters and calorific power of $E$. urograndis charcoal between position interaction and carbonization ramp.

Table 6. ANOVA of volatile materials, fixed carbon, ash and calorific value of E. urograndis charcoal. Tabela 6. ANOVA dos materiais voláteis, carbono fixo, cinzas e poder calorífico do carvão de $E$. urograndis.

\begin{tabular}{cccc}
\hline Parameters & Positions & Ramps & P \\
\hline Volatile Materials $(\%)$ & ns & $* *$ & $* *$ \\
Fixed Carbon $(\%)$ & $*$ & $* *$ & $* *$ \\
Ashes $(\%)$ & $* *$ & $* *$ & $* *$ \\
Calorific power $(\%)$ & $*$ & $* *$ & $* *$ \\
\hline
\end{tabular}

** significant at $1 \%$ probability level; $*$ significant at $5 \%$ probability level; ns - not significant

The analysis of variance of the Immediate Chemical Analysis in Table 6 shows no significant difference for volatile materials between positions, and significant differences at the $1 \%$ probability level between the two different Carbonization Ramps and between the Ramp-Position interaction. There was a significant difference at $5 \%$ probability between positions for fixed carbon, and significant differences at $1 \%$ probability level between the two different Carbonization Ramps and between the Ramp-position interaction. There was also a significant difference at the $1 \%$ probability level for ashes between positions, Ramps and Ramp-Position interaction. Lastly, the calorific power presented significant positions at 5\% probability, the Ramp and a significant Ramp-position interaction at $1 \%$ probability.

Table 7 shows the average test values for the parameters of the immediate chemical analysis and the calorific power of E. urograndis charcoal.

Table 7. Average values of volatile materials, fixed carbon, ash and calorific power of E. urograndis charcoal. Tabele7. Averages of volatile materials, fixed carbon, ash and calorific value of $E$. urograndis charcoal.

\begin{tabular}{cccc}
\hline & & \multicolumn{2}{c}{ Carbonization Ramps } \\
\hline Parameters & Positions & $\mathbf{4 5 0}^{\circ} \mathbf{C}$ & $\mathbf{5 0 0}^{\circ} \mathbf{C}$ \\
\hline & Base & $25.47 \mathrm{abA}$ & $21.24 \mathrm{aB}$ \\
Volatile Materials & & $(1.50 ; 5.88)$ & $(0.98 ; 4.61)$ \\
$(\%)$ & DBH & $26.10 \mathrm{aA}$ & $18.60 \mathrm{bB}$ \\
& & $(1.72 ; 6.58)$ & $(1.00 ; 5.38)$ \\
& Top & $24.52 \mathrm{bA}$ & $21.74 \mathrm{aB}$ \\
& & $(1.11 ; 4.54)$ & $(1.56 ; 7.17)$ \\
\hline \multirow{2}{*}{ Fixed Carbon $(\%)$} & Base & $73.87 \mathrm{abB}$ & $78.17 \mathrm{bA}$ \\
& & $(1.49 ; 2.01)$ & $(0.98 ; 1.26)$ \\
& DBH & $73.46 \mathrm{bB}$ & $80.96 \mathrm{aA}$ \\
& & $(1.72 ; 2.35)$ & $(1.00 ; 1.23)$
\end{tabular}




\begin{tabular}{cccc}
\hline & Base & $0.66 \mathrm{aA}$ & $0.59 \mathrm{aB}$ \\
& & $(0.04 ; 6.14)$ & $(0.04 ; 6.35)$ \\
Ashes $(\%)$ & DBH & $0.44 \mathrm{bA}$ & $0.43 \mathrm{bA}$ \\
& & $(0.02 ; 4.21)$ & $(0.02 ; 5.65)$ \\
& Top & $0.46 \mathrm{bA}$ & $0.45 \mathrm{bA}$ \\
& & $(0.02 ; 4.08)$ & $(0.03 ; 6.40)$ \\
\hline & Base & $7392.09 \mathrm{abB}$ & $7535.16 \mathrm{bA}$ \\
Calorific power & DBH & $(49.50 ; 0.67)$ & $(32.66 ; 0.43)$ \\
$(\%)$ & & $7378.57 \mathrm{bB}$ & $7628.13 \mathrm{aA}$ \\
& Top & $(57.32 ; 0.78)$ & $(33.21 ; 0.44)$ \\
& & $7430.2 \mathrm{aB}$ & $7523.28 \mathrm{bA}$ \\
& & $(36.85 ; 0.50)$ & $(51.54 ; 0.69)$ \\
\hline
\end{tabular}

The average followed by the same uppercase letter in the row and the same lowercase letter in the column do not differ statistically from each other by the Tukey test (5\%). The values in parentheses respectively correspond to standard deviation and coefficient of variation (\%).

\section{DISCUSSION}

\section{Wood Characterization}

Table 3 shows that the average for the basic wood density parameter decreased in the base-top direction due to the fact that the fibers have a thicker cell wall at the base and are less thick at the top for fact that the top has more youthful wood and the base is adult wood. The average result from the base was $0.50 \mathrm{~g} / \mathrm{cm}^{3}$ and from the top $0.44 \mathrm{~g} / \mathrm{cm}^{3}$, so all positions presented significant differences at the $5 \%$ probability level. The average values of $E$. urograndis wood sample density from this study were similar but lower than those found by Gonçalez et al. (2014) of $0.51 \mathrm{~g} / \mathrm{cm}^{3}$ for 8 year-old E. urograndis, and of $0.54 \mathrm{~g} / \mathrm{cm}^{3}$ by Santos et al. (2011) for Eucalyptus clones at seven years of age.

Basic wood density is considered an index for wood quality assessment, being one of the most relevant indicators to be evaluated among the various physical properties, as it can affect the others, especially the energy properties since wood density directly interferes with the charcoal density, its yield and quality. According to Coradin et al. (2010) and Silveira et al. (2013), woods are classified as light or low density $\left(<0.550 \mathrm{~g} / \mathrm{cm}^{3}\right)$, medium density (between 0.550 and $0.720 \mathrm{~g} / \mathrm{cm}^{3}$ ) and heavy or high density $\left(>0.730 \mathrm{~g} / \mathrm{cm}^{3}\right)$. The higher the density, the more fixed carbon, the higher the calorific value, and the greater the energy potential. E. urograndis wood presented average basic density values which are considered low $\left(0.46 \mathrm{~g} / \mathrm{cm}^{3}\right)$, mainly in the top position, which classifies it as low density wood. This factor may be linked to the tree age and environmental conditions.

Regarding the retractability (presented in Table 2), there was also a decrease of the average value in the basetop direction for the tangential shrinkage parameter, with a maximum average of $7.13 \%$ and a minimum of $6.12 \%$, in which the position from the base differed statistically from the others at the $5 \%$ probability level. The averages were lower than that found by Batista et al. (2010), which was $9.25 \%$ for E. grandis.

There was a small variation in the averages for the radial shrinkage and longitudinal shrinkage parameters (Table 3), with the positions being statistically equal. The radial retraction average was $4.35 \%$ maximum and $4.27 \%$ minimum, which is close to that found by Batista et al. (2010) which was $4.60 \%$ for E. grandis. The average for longitudinal retraction was insignificant.

There was a decrease in the average for the volumetric shrinkage parameter in the base-top direction, with a maximum average of $11.64 \%$ and a minimum of $10.58 \%$, thus resulting in a significant difference between the base and top at the $5 \%$ probability level, and meaning that the wood from the top has greater dimensional stability. The average volumetric retraction rate found by Batista et al. (2010) for E. grandis was higher, $14.10 \%$, which means that the $E$. urograndis species studied in the present work has lower retractability, and therefore greater dimensional stability.

The anisotropic factor (still in Table 3), showed little variability of averages, where there was no statistical difference between one position from another. The average values of this factor ranged from 1.44 to 1.66 , consequently lower than the average found by Batista et al. (2010) for E. grandis which was 2.05. The anisotropic factor is a paramount parameter for assessing the dimensional stability of wood. Following classification criteria, the wood of the species in this study is classified as normal at the base and excellent at the top for its dimensional stability.

\section{Charcoal Characterization}

Table 4 compares the charcoal yield in condensable and non-condensable gases between the different trunk positions and the different carbonization Ramps, in which the highest charcoal yield was based on the $450^{\circ} \mathrm{C}$ carbonization Ramp with a value of $33.33 \%$, and the smallest was from the top in the $500^{\circ} \mathrm{C}$ Carbonization Ramp with a value of $30.12 \%$. These values are similar to those of Oliveira et al. (2010), in which the E. pellita species for the same $450^{\circ} \mathrm{C}$ Ramp obtained $32.11 \%$ in charcoal yield, and a value of $31.09 \%$ for the same $500^{\circ} \mathrm{C}$ Carbonization Ramp. Vieira et al. (2013) found an average of $34 \%$ for Eucalyptus micocorys at the final temperature of $500^{\circ} \mathrm{C}$. Soares et al. (2015) produced charcoal with yields of $33.06 \%$ with Eucalyptus at seven years of age at the final temperature of $450^{\circ} \mathrm{C}$. It can be observed that higher temperature carbonization ramps tend to produce lower charcoal yields. Vilas Boas (2010) 
reports that this occurs due to the decomposition of the chemical constituents of wood, causing mass loss and consequently a loss in charcoal yield. It was also observed that the base tends to have higher yield because it has higher density compared to the top. Higher densities result in higher charcoal yield.

The yield for condensable gases (Table 4 ) was higher at the top for the $450^{\circ} \mathrm{C}$ Carbonization Ramp with a value of $50.00 \%$ and lower at the base for the $500^{\circ} \mathrm{C}$ Carbonization Ramp with a value of $44.51 \%$. These values are slightly lower than those of Oliveira et al. (2010), in which the E. pellita species obtained $58.95 \%$ in condensable gas yield for the same $450^{\circ} \mathrm{C}$ Ramp, and $58.98 \%$ for the same $500^{\circ} \mathrm{C}$ Ramp. In a study with the Corymbia citriodora species and species of the Eucalyptus genus, Zanuncio et al. (2015) showed a lower average value of $31.05 \%$ for the Corymbia citriodora species at the final temperature of $450^{\circ} \mathrm{C}$. The carbonization ramps in the present work significantly interfered in the pyroligneous liquor yield, with the lowest temperature increase being the most efficient for this parameter.

The non-condensable gas yield (Table 4) was higher in the $\mathrm{DBH}$ for the $450^{\circ} \mathrm{C}$ Carbonization Ramp with a value of $23.38 \%$, and lower for the same Carbonization Ramp with a value of $19.05 \%$. These values are much higher than those found by Oliveira et al. (2010), in which the E. pellita species obtained a non-condensable gas yield of $8.93 \%$ for the same Ramp of $450^{\circ} \mathrm{C}$. Assis et al. (2012) studied the quality and yield of charcoal from a hybrid Eucalyptus grandis x Eucalyptus urophylla crossover clone and found higher average values for non-condensable gases of $28.89 \%$ at the final temperature of $450^{\circ} \mathrm{C}$. Non-condensable gases as well as condensable gases have achieved high yields, and these can be harnessed in the energy industry as a source of energy through the dry distillation process that can be implanted from retorts rather than conventional ovens. The present work presented considerable yields, and thus the $E$. urograndis species can be considered as a good energy source.

The apparent density (Table 5) decreased in the base-top direction, as seen in the basic density, as they are similar parameters. The density of charcoal and the density of its source wood are correlated, and therefore there is a correlation between them, which indicates that the type of wood is determinant in the final density of charcoal. The highest apparent density was from the base with a value of $0.35 \mathrm{~g} / \mathrm{cm}^{3}$ in the two different carbonization ramps. The lowest apparent density was $0.23 \mathrm{~g} / \mathrm{cm}^{3}$, with this same value at the top and $\mathrm{DBH}$ of the $450^{\circ} \mathrm{C}$ and $500^{\circ} \mathrm{C}$ carbonization ramps, respectively. The average apparent density values of $E$. urograndis in the present study were similar to those found by Santos et al. (2011), of 0.27 to $0.35 \mathrm{~g} / \mathrm{cm}^{3}$ in a study conducted with Eucalyptus clones by Oliveira et al. (2010), and in a study with Eucalyptus pellita $\mathrm{F}$. Muell in which the authors found averages ranging from 0.353 to $0.368 \mathrm{~g} / \mathrm{cm}^{3}$.

The base and top had a significant statistical difference in the carbonization Ramp of $450^{\circ} \mathrm{C}$. In contrast, the positions which had a significant difference were in the base and in $\mathrm{DBH}$ in the carbonization Ramp of $500^{\circ} \mathrm{C}$. In general, the base stood out with higher densities, with this being an important feature for the load composition in the kiln, as the higher the charcoal density, the smaller the volume occupied by it and the higher the yield.

The breaking index (Table 5) also tended to be higher at the base, coinciding with the density and retractability which were higher at the base, and can be explained by the fact that the denser the specimen, the greater the impact on the fall which influenced the breaking, in addition to greater retractability in the base, meaning lower dimensional stability, thus influencing the index by possible cracks in the carbonization process of charcoal, which decreases its resistance. However, the species of the present work generally presented significantly low data average, meaning that the species is resistant to breakage. The highest value was $0.74 \%$ of base in the $450^{\circ} \mathrm{C}$ Carbonization Ramp and the lowest was $0.15 \%$ of the top and $\mathrm{DBH}$ for the $450^{\circ} \mathrm{C}$ and $500^{\circ} \mathrm{C}$ Carbonization Ramps, respectively. The base had a statistically significant difference from the other positions in the Carbonization Ramp of $450^{\circ} \mathrm{C}$, while there were no significant differences in the Carbonization Ramp of $500^{\circ} \mathrm{C}$.

Table 7 presents the ICA and calorific value data. The highest values for volatile materials were for the $450^{\circ} \mathrm{C}$ Carbonization Ramp with the largest DBH value (26.10\%), and the lowest values of the $500^{\circ} \mathrm{C}$ Ramp was the lowest DBH value (18.60\%), constituting higher values than those found by Oliveira et al. (2010) for the E. pellita species of $12.04 \%$ and $11.15 \%$ in the $450^{\circ} \mathrm{C}$ and $500^{\circ} \mathrm{C}$ Ramps, respectively. In studying Eucalyptus clones, Reis et al. (2013) also found average values close to this study of $26.04 \%$ for the final temperature of $450^{\circ} \mathrm{C}$. In their study with Eucalyptus clones, Chaves et al. (2013) found close averages ranging from $24.63 \%$ to $19.59 \%$. Furthermore, in a study with Eucalyptus benthamii, Nones et al. (2015) observed a high average content of $30.41 \%$. Volatile materials are responsible for ignition of the material, and it is interesting to have a value less or equal to $25.00 \%$, which constitutes the value resulting from the data of resolution SAA - 40 (2015), and defines values for fixed carbon and ash. The values of the present work for the volatile materials parameter were approximately $25.00 \%$, which is ideal. The carbonization ramps were statistically different from each other, the positions were statistically different between DBH and the top in the $450^{\circ} \mathrm{C}$ ramp, while $\mathrm{DBH}$ in the $500^{\circ} \mathrm{C}$ ramp was the position that differed from the others.

The highest values for fixed carbon were for the $500^{\circ} \mathrm{C}$ Carbonization Ramp, with the largest being the DBH value $(80.96 \%)$, and the lowest values of the $450^{\circ} \mathrm{C}$ Ramp being the lowest $\mathrm{DBH}$ value $(73.46 \%)$. These values are lower than those found by Oliveira et al. (2010) for the E. pellita species of $86.10 \%$ and $86.66 \%$ in the $450^{\circ} \mathrm{C}$ and $500^{\circ} \mathrm{C}$ Ramps, respectively; and by Reis et al. (2013), who found average values between $71.74 \%$ and $76.93 \%$ for species of the Eucalyptus genus, with the values being considered close to those observed in this study for three species of the Eucalyptus genus. Fixed carbon is a parameter of great importance for the calorific power of charcoal, as they have direct proportionality. Resolution SAA - 40 (2015) recommends approximately $73.00 \%$ fixed carbon for good quality charcoal. The values of the present work were approximate, thus defining the E. urograndis species as being optimal for energy potential. The carbonization ramps were statistically different from each other, the positions were statistically 
different between $\mathrm{DBH}$ and top in the $450^{\circ} \mathrm{C}$ ramp, and $\mathrm{DBH}$ in the $500^{\circ} \mathrm{C}$ ramp was the position that differed from the others. Since the volatile material and fixed carbon levels are inversely proportional, the lowest value for fixed carbon was observed in the treatment with the highest value for volatile material, and vice versa.

The highest value for ash content was $0.66 \%$ for the base at the $450^{\circ} \mathrm{C}$ Carbonization Ramp, while the lowest value was $0.43 \%$ for the $\mathrm{DBH}$ at the $500^{\circ} \mathrm{C}$ Ramp. These values are lower than those found in the study by Oliveira $e t$ al. (2010) for the E. pellita species, which were $1.86 \%$ and $2.19 \%$ in the $450^{\circ} \mathrm{C}$ and $500^{\circ} \mathrm{C}$ Ramps, respectively. In a study with Eucalyptus hybrids of different ages, Soares et al. (2015) found ash content at five years of age of $0.87 \%$, being higher than the values of the present study. Ashes are not useful for energy use, as they have no purpose in Energy production; they constitute a waste which can cause corrosion and require greater maintenance in boilers when in large quantities, so the lower the ash content the better for the industry, as this means less waste and less maintenance costs. Resolution SAA - 40 (2015) recommends a value of less than $1.50 \%$ of ashes, and the ash content of the present work was much lower than recommended, thus characterizing the E. urograndis species as a great alternative for charcoal production due to generating little waste in the energy industry. The carbonization ramps only had a significant difference for the base position, and the base differed significantly from the other positions.

The calorific value (still in Table 7) presented higher values in the Carbonization Ramp of $500^{\circ} \mathrm{C}$, and the highest value was $7628.13 \mathrm{kcal} / \mathrm{kg}$, but it was lower than that found in the same $500^{\circ} \mathrm{C} \mathrm{Ramp}$ for E. pellita in the work of Oliveira et al. (2010), which was $8237.00 \mathrm{kcal} / \mathrm{kg}$. The DBH position in this Ramp presented significant difference from the other positions in the present study. The carbonization Ramp of $450^{\circ} \mathrm{C}$ presented the lowest values, with the lowest being $7378.57 \mathrm{kcal} / \mathrm{kg}$, which is lower than that found in the same Ramp of $450^{\circ} \mathrm{C}$ for E. pellita in of 8309.00 $\mathrm{kcal} / \mathrm{kg}$ the study by Oliveira et al. (2010). In a study conducted with the Corymbia citriodora species and species of the Eucalyptus genus, Zanuncio et al. (2015) found a value of $7545.41 \mathrm{kcal} / \mathrm{kg}$ at the final temperature of $450^{\circ} \mathrm{C}$, close to the values found in this study. the DBH and top positions in this Ramp presented a statistically significant difference. All positions had significant difference in the comparison between the two different Carbonization Ramps, and therefore the Carbonization Ramp significantly interferes in the calorific value because it directly interferes with the fixed carbon content.

The calorific power values can be explained due to the existence of a positive correlation between the calorific value and the fixed carbon content, as evidenced by the calculated $\mathrm{R}$ value (1.00), which shows a strong positive correlation between the two parameters.

\section{CONCLUSIONS}

According to what was found, it is concluded that:

- The retractibility of E. urograndis wood showed values which characterize the wood as more stable when compared to other Eucalyptus species. For energy purposes, this is a good feature to look into in order to ensure less cracked charcoal and higher strength.

- The basic wood density was considered low $\left(<0.550 \mathrm{~g} / \mathrm{cm}^{3}\right)$;

- The apparent density of E. urograndis charcoal was in compliance with the literature for the Eucalyptus genus;

- The charcoal yield was higher in the base and had no interference from the carbonization ramps. It presented high values compared to other works, and high charcoal yield is synonymous with high production.

- The yields for condensable and non-condensable gases were significant, since the condensable gases showed a high yield and can be used for various purposes as fertilizer, disinfectant, sterilizer, as a food additive, and for energy purposes.

- The breaking index of charcoal was low, thus being characterized as resistant to breakage.

- The fixed carbon content was inversely proportional to the volatile content, and were generally considered ideal values for high quality charcoal. The ash content was low, which is interesting as ash is not useful for energy purposes.

- The superior calorific value was within the stated standards for good quality charcoal.

- Overall, the results were within those recommended by resolution SAA - 40 (2015), thus characterizing Eucalyptus urograndis as a good option for energy production in the state of Tocantins.

\section{REFERENCES}

ABRAF. Anuário estatístico da ABRAF 2013: ano base 2012. ABRAF - Brasília, 2013.

AMERICAN SOCIETY FOR TESTING AND MATERIALS - ASTM. D1762-84: standard method for chemical analyses of wood charcoal. Philadelphia, p.2, 2007.

AMERICAN SOCIETY FOR TESTING AND MATERIALS - ASTM. D-2395: standard test methods for specific gravity of wood and wood-based materials. Philadelphia, p.8, 2005.

ASSIS, M. R. D.; PROTÁSIO, T. P.; ASSIS, C. O.; TRUGILHO, P. F.; SANTANA, W. M. S. Qualidade e rendimento do carvão vegetal de um clone híbrido de Eucalyptus grandis x Eucalyptus urophylla. Pesquisa florestal Brasileira, Colombo, PR, v. 32, n. 71, p. 291-302, jul./set. 2012. 
ASSOCIAÇÃO BRASILEIRA DE NORMAS TÉCNICAS - ABNT. NBR 7416: carvão vegetal: determinação do índice de quebra. Rio de Janeiro, 1984.

BATISTA, D. C.; KLITZKE, R. J.; SANTOS, C. V. T. Densidade básica e retratibilidade da madeira de clones de três espécies de Eucalyptus. Ciência Florestal, Santa Maria, v.20, n.4, p. 665-674, 2010.

CHAVES, A. M. B.; DO VALE, A. T.; MELIDO, R. C. N.; ZOCH, V. P. Características energéticas da madeira e carvão vegetal de clones de Eucalyptus spp. Enciclopédia Biosfera, Centro Científico Conhecer - Goiânia, v.9, n.17, 2013, 533p.

Coradin, V.T.R.; Camargos, J.A.A.; Pastore, T.C.M.; Christo, A.G. 2010. Madeiras comerciais do Brasil: chave interativa de identificação baseada em caracteres gerais e macroscópicos. (http://www.ibama.gov.br/lpf/madeira/introducao.htm). Acesso em 02/12/2018.

COMISSION PANAMERICANA DE NORMAS TECNICAS. COPANT 462: Maderas: método de determinación de la contracción. Caracas, 1972.

VALE, A. T. do; ABREU. V. L. S.; GONÇALES, J. C.; COSTA. A. F. da. Estimativa do poder calorífico superior do carvão vegetal de madeiras de Eucalyptus grandis em função do teor de carbono fixo e do teor de material volátil. Brasil Florestal, $\mathrm{n}^{\circ} 73,2002$.

FOOD AND AGRICULTURE ORGANIZATION OF THE UNITED NATIONS - FAO. 2017. Avaliable from: <http://www.fao.org/forestry/energy/en/>. Access on: 30 nov. 2017.

GONÇALEZ, J. C.; SANTOS, G. L.; SILVA JUNIOR, F. G.; MARTINS, I. S. COSTA, J. A. Relações entre dimensões de fibras e de densidade da madeira ao longo do tronco de Eucalyptus urograndis. Scientia Forestalis, Piracicaba, v. 42, n. 101, p. 81-89, março de 2014.

OLIVEIRA, A. C.; CARNEIRO, A. C. O; VITAL, B. R.; ALMEIDA, W.; PEREIRA, B. L. C.; CARDOSO, M. T. Parâmetros de qualidade da madeira e do carvão vegetal de Eucalyptus pellita F. Muell. Scientia Forestalis, Piracicaba, V. 38, n. 87 , p. $431-439,2010$.

REIS, C. A.; ASSIS, T. F.; SANTOS, A. M.; FILHO, E. P. Corymbia citriodora: estado da arte de pesquisa no Brasil. Colombo: Embrapa Florestas, 2013. 59 p. (Embrapa Floresta. Documento 255).

Resolução SAA - 40 de 14 de dezembro de 2015. Define Norma de Padrões Mínimos de Qualidade para Carvão Vegetal, como base para Certificação de Produtos pelo Sistema de Qualidade de Produtos Agrícolas, Pecuários e Agroindustriais do Estado de São Paulo, 2015.

SANTOS, A. F. dos; AUER, C. G.; RODRIGUES, L. M. R.; RODRIGUES NETO, J. Ocorrência de mancha foliar bacteriana em plantios de eucalipto no estado de Mato Grosso e de Santa Catarina. Tropical Plant Pathology, Lavras, v.35, p.232, 2010. Suplemento.

SANTOS, R. C.; CARNEIRO, A. C. O.; CASTRO, A. F. M.; CASTRO, R. V. O.; BIANCHE, J. J.; SOUZA, M. M.; CARDOSO, M. T. Correlações entre os parâmetros de qualidade da madeira e do carvão vegetal de clones de eucalipto. Scientia Forestalis, Piracicaba, v. 39, n. 90, p. 221-230, jun. 2011.

SILVEIRA, L. H. C.; REZENDE, A. V.; VALE, A. T. Teor de umidade e densidade básica da madeira de nove espécies comerciais amazônicas. Acta Amazônica, Manaus, v. 43, n. 2, p. 179-184, 2013.

SOARES, V. C.; BIANCHI, M.L.; TRUGILHO, P.F.; HOFLER, J.; PEREIRA, A.J. Análise das propriedades da madeira e do carvão vegetal de híbridos de Eucalyptus em três idades. Cerne, Lavras, MG. v. 21, n. 2, p. 191-197, abr./jun. 2015.

VIEIRA, R. D. S.; LIMA, J.T.; MONTEIRO, T.C.; SELVATTI, T.S.; BARAÚNA, E.E.P.; NAPOLI, A. Influência da temperatura no rendimento dos produtos da carbonização DE Eucalyptus microcorys. Cerne, Lavras, MG. v. 19, n. 1, p. 59-64, jan./mar. 2013.

VILAS BOAS, M. A., CARNEIRO, A. C. O., VITAL, B. R.; CARVALHO, A. M. M. L., MARTINS, M. A. Efeito da temperatura de carbonização e dos resíduos de macaúba na produção de carvão vegetal. Scientia Forestalis, Piracicaba, SP. v. 38, n. 87, p. 481-490, 2010.

ZANUNCIO, A. J. V.; CARVALHO, A.G.; SILVA, E.M.G.C.; MONTEIRO, T. C.; LIMA, J. T.; SILVA, J. R. M. Da. Propriedades energéticas da madeira e carvão de Corymbia e Eucalyptus em diferentes condições de secagem. Revista Brasileira de Ciências Agrárias. Recife, PE, v. 10, n. 3, p. 432-436, jan. 2015. 